\title{
10. BIOSTRATIGRAPHIC IMPLICATIONS OF NEOGENE BENTHIC FORAMINIFERS FROM SITE 468, SOUTHERN CALIFORNIA CONTINENTAL BORDERLAND: A PRELIMINARY STUDY1
}

\author{
Gregg H. Blake, Union Oil Company of California, Ventura, California
}

\section{INTRODUCTION}

In recent years there has been considerable discussion concerning the biostratigraphic correlations between planktonic zonations and the classical Neogene California benthic foraminiferal stages. One of the primary objectives of IPOD Leg 63 was to investigate these correlations and to determine the possibility of temporal variation of the benthic stages between California land sections and the outer Continental Borderland. In addition, it was anticipated that analyses of the benthic foraminiferal faunas at Site 468 would provide critical information on the paleoenvironmental history of the outer borderland.

The provincial benthic Neogene foraminiferal stages were established by Kleinpell (1938) for the Miocene and Natland (1952) for the Pliocene-Pleistocene; both are well-documented in designated type sections. These stages have been used for interbasinal correlations, although time-transgressive problems have been suggested by several authors (Bandy, 1971; Ingle, 1967, 1973; Crouch and Bukry, 1979).

An important biostratigraphic sequence occurs at Site 468 , significant because of its relatively shallow depth of approximately 1700 meters (Fig. 1). The samples yield well-preserved benthic foraminiferal faunas throughout most of the Neogene sequence and are accompanied by abundant well-preserved calcareous and siliceous planktonic assemblages. It is this co-occurrence of both planktonic and benthic faunas that enables the correlation of outer continental margin sediments with those of the classical land-based sections of southern California.

\section{METHODS AND PROCEDURES}

A total of 41 samples from Holes $468 \mathrm{~A}$ and $468 \mathrm{~B}$ were examined for this preliminary study. All samples were collected aboard the Glomar Challenger as a part of the planktonic foraminiferal analyses. Samples obtained generally consisted of $10 \mathrm{~cm}^{3}$ of sediment. The majority of samples were unconsolidated and were washed through a $200-\mu \mathrm{m}$ screen and dried.

Quantitative analyses were made for both Holes 468A and 468B. Three hundred benthic specimens were counted and recorded as a percentage of the total number. For samples with large numbers of specimens, the sample was subdivided into aliquots with an Otto microsplitter, and one or more of the aliquots were counted as the basis for estimating the total population.

The raw data were classified by cluster analysis using a Bray-Curtis distance coefficient to determine the major fossil assemblages. Before each data set was subjected to cluster analysis, the species were

\footnotetext{
${ }^{1}$ Initial Reports of the Deep Sea Drilling Project, Volume 63.
}

ordered by the number of occurrences in the samples being studied. Species accounting for less than $5 \%$ of the total occurrences were deleted from the data and not used for further cluster analysis. It has been shown that this procedure does reflect the statistical integrity of the total population (Blake, 1976).

The raw data were standardized using species-mean and speciesmaximum standardizations. Both the species maximum and species mean are measures of the general abundance of a species when it is present. These standardizations are more consistent with biologically meaningful associations (Smith, 1976).

The cluster analysis resulted in the identification of well-defined groups that can be shown to be habitat related. Groupings were given Biofacies designations on the basis of characteristic species included in each group and their close faunal affinities with the other groups. Depth classification of the biofacies are modified from Ingle (1973) and shown in Table 1.

\section{SITE 468}

South of the northern Channel Islands, the southeast-trending Patton Escarpment forms a west-facing slope (1.5-3.5 km high) that separates the California Continental Borderland from oceanic crust of the $\mathrm{Pa}$ cific plate. At about $32^{\circ} 49^{\prime} \mathrm{N}$ latitude, the Patton Escarpment is cut by an elongate shallow trough that opens westward toward the Pacific Ocean (Fig. 1). Site 468 is located on the north side of this trough.

Holes 468, 468A, and 468B were drilled on the northeast portion of the elongate trough. Hole problems forced termination of drilling in Hole 468, and a broken sand line forced termination of drilling in Hole 468A. Holes 468A and 468B are located at 1740 meters water depth about $1.2 \mathrm{~km}$ upslope from Hole 468 . Hole 468B was spudded without changing position from $468 \mathrm{~A}$; because of this, these two holes were used for this preliminary study. Together, these two holes provide a fairly continuous sedimentary sequence from 0 to 240 meters sub-bottom depth. Hole $468 \mathrm{~A}$ is 35.5 meters in depth and Hole 468B was drilled to a total sub-bottom depth of 415.5 meters.

\section{Hole 468A}

\section{Lithologic Units}

The first unit penetrated consists mainly of a light, olive gray, glauconitic nannofossil foraminiferal ooze and silty ooze. Benthic and planktonic foraminifers are the predominant components (up to $50 \%$ ) of the sediments. The boundary between Units 1 and 2 in Hole $468 \mathrm{~A}$ is in Core 1 , Section 5 (approximately $7 \mathrm{~m}$-Fig. 2). Unit 2 is composed of very soft, interbedded, pale olive foraminiferal nannofossil ooze and an olive brown nannofossil foraminiferal ooze. Minor constituents include thin intervals of glauconitic silty sand and silty clay. 


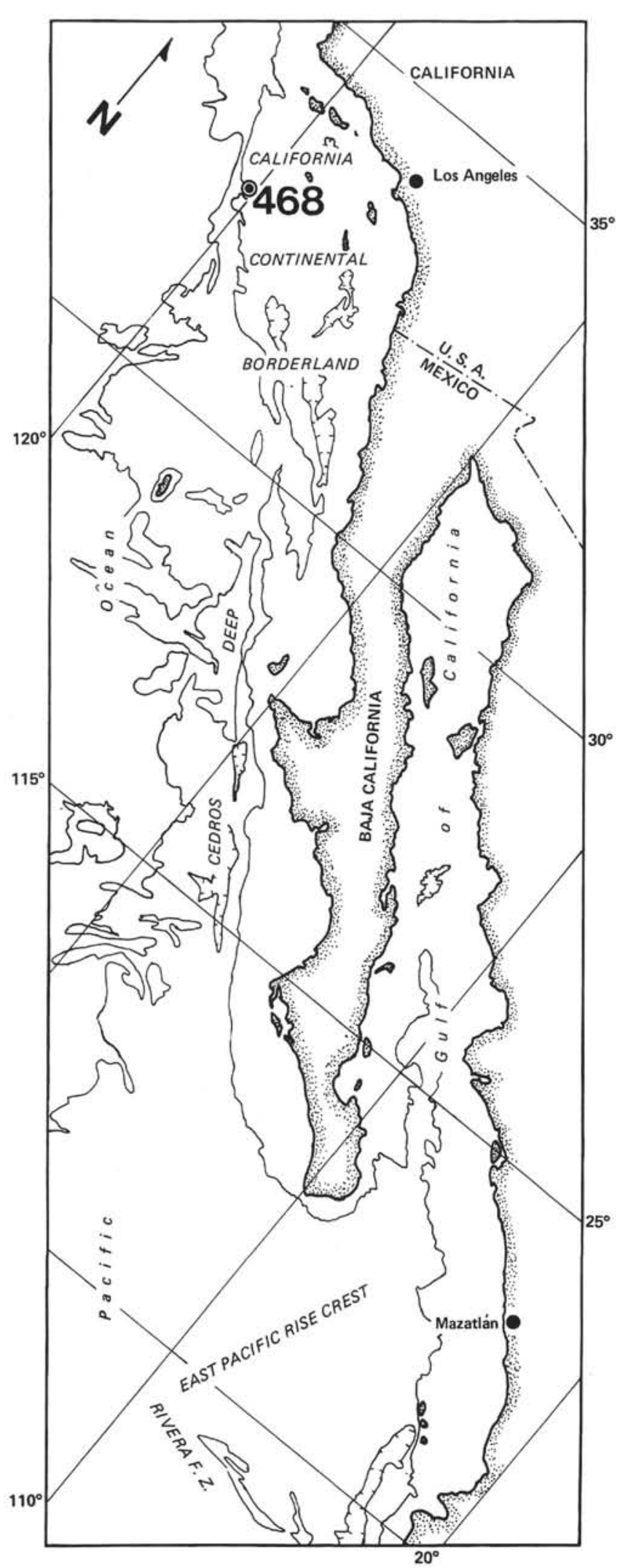

Figure 1. Location map of Site 468.
Table 1. Depth classification of benthic foraminiferal biofacies.

\begin{tabular}{lc}
\hline \multicolumn{1}{c}{ Benthic Biofacies } & $\begin{array}{c}\text { Present Depth Range } \\
\text { (m) }\end{array}$ \\
\hline Inner neritic & $0-50$ \\
Outer neritic & $50-150$ \\
Upper bathyal & $150-500$ \\
Upper middle bathyal & $500-1500$ \\
Lower middle bathyal & $1500-2300$ \\
Lower bathyal & $2300-4000$ \\
Abyssal & $4000-6500$ \\
\hline & \\
a These depth ranges are applied only to present \\
conditions in the eastern Pacific Ocean; they \\
are not meant to represent depth-habitat \\
boundaries in the fossil record (from Ingle, \\
1973).
\end{tabular}
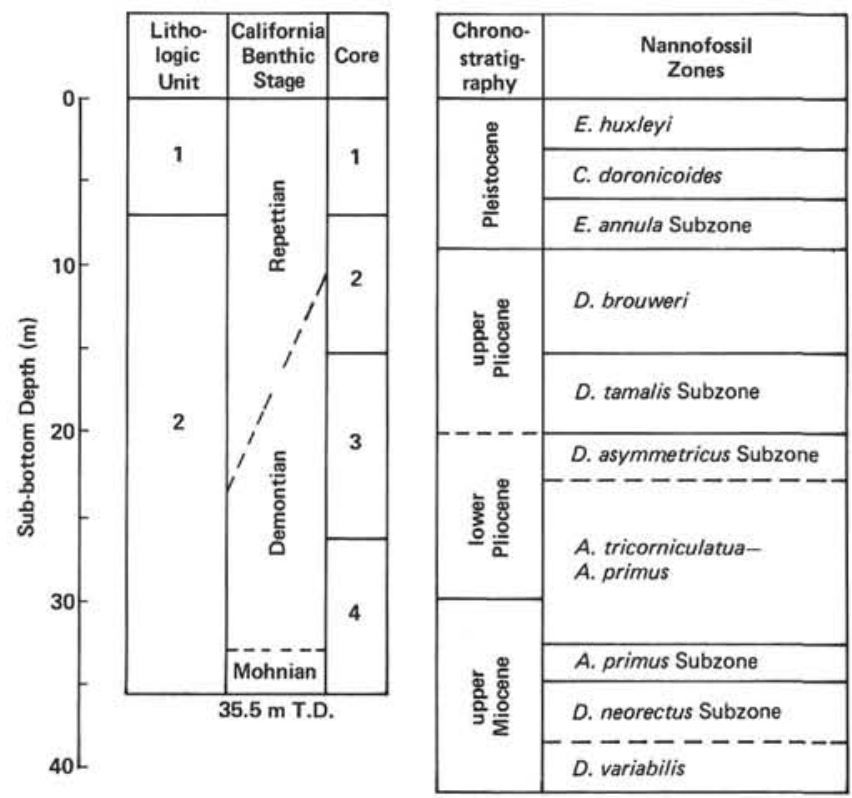

Figure 2. Biostratigraphic correlation of benthic foraminiferal stages to nannofossil zones in Hole 468A.

\section{Preservation}

Benthic foraminiferal faunas are abundant and wellpreserved in the upper Neogene sediments. Using the planktonic to benthic ratio (P/B ratio) as an approximate index of preservation and dissolution, the majority of samples appears to be relatively unaffected by dissolution. Values for Cores 1 through 3 range from 4.8 to 1.1 (Table 2). In the last core (Core 4), dissolution has become a dominant factor, and the $\mathrm{P} / \mathrm{B}$ values drop to 0.08 to 0.01 . On the basis of the relatively well-preserved nature of the benthic specimens, it can only be assumed that the residual assemblage is statistically similar to the original populations; i.e., any destruction of foraminiferal tests would have a negligible effect on the statistically dominant species. 
Table 2. Planktonic/benthic ratios, Site 468.

\begin{tabular}{lc}
\hline $\begin{array}{c}\text { Sample } \\
\text { (interval in cm) }\end{array}$ & P/B Ratio \\
\hline 468A-1-1, 138-140 & 4.77 \\
468A-1-3, 130-132 & 3.55 \\
468A-1-5, 40-42 & 14.00 \\
468A-2-3, 90-92 & 1.03 \\
468A-2-5, 80-82 & 1.10 \\
468A-2,CC, & 5.02 \\
468A-3-3, 70-72 & 1.00 \\
468A-3,CC & 0.03 \\
468A-4-1, 60-62 & 0.08 \\
468A-4-3, 58-60 & 0.01 \\
468A-4,CC & 0.01 \\
468B-1-1, 60-62 & 1.02 \\
468B-1,CC & 0.99 \\
468B-2-1, 110-112 & 0.10 \\
468B-3-1, 15-17 & 0.04 \\
468B-4-1, 110-112 & 0.017 \\
468B-6-1, 110-112 & 0.00 \\
468B-8-1, 100-102 & 0.00 \\
468B-8-3, 80-82 & 0.00 \\
468B-9-1, 60-62 & 0.00 \\
468B-10-2, 58-60 & 0.01 \\
468B-12-1, 0-2 & 0.01 \\
468B-13-1, 58-60 & 0.04 \\
468B-13-1, 73-75 & 0.02 \\
468B-14-1, 86-88 & 0.02 \\
468B-15-1, 41-43 & 0.04 \\
468B-17-4, 56-58 & 0.00 \\
\hline
\end{tabular}

\section{Benthic Foraminiferal Stages}

Hole 468A contains an upper Miocene to Pleistocene section that consists of foraminiferal assemblages. The entire section is dominated by several species that are characteristic of the Repettian stage as defined by Natland (1952). The majority of these species represent lower bathyal environments and include Melonis pompilioides, Uvigerina proboscidea, Bulimina rostrata, Pullenia bulloides, and Uvigerina senticosa. All of these species are indicative of environments that have a present depth range of between 2300 to 3500 meters in the eastern Pacific Ocean (Bandy, 1953; Bandy and Chierici, 1966). In addition, several species occur that are displaced from shallower middle and upper bathyal depths; these are Cassidulina subglobosa, Bulimina subacuminata, Epistominella bradyana, Cassidulina cushmani, and Eponides tenera.

It is very difficult to apply stage designations in Hole 468A because of the dominance of the Repettian fauna within the benthic foraminiferal assemblage. Consequently, the upper Neogene stage designations are determined on the basis of a relatively small percentage of constituents of the total faunal assemblage. In Section 468A-4-5 (at $33 \mathrm{~m}$ ), there is the first occurrence of an assemblage that is indicative of the Delmontian and/or Mohnian benthic stages (Fig. 2). This assemblage includes Bolivina sinuata, Bolivina floridana, Bulimina inflata, Pullenia pedroana, and Cassidulina crassa. As the calcareous nannofossils indicate, this interval would be within the $A$. primus Subzone (Bukry, this volume), or the upper Miocene.
The cluster analysis of the fauna from this hole resulted in defining five recurrent groups in the R-mode or inverse analysis (Fig. 3). The first grouping (Lower Middle Bathyal Biofacies) of predominantly lower middle bathyal species includes Bulimina mexicana, Melonis barleeanum, Pullenia bulloides, Bulimina subacuminata, Uvigerina hispida, and Cassidulina laevigata carinata. In addition, there are species that are displaced from shallower bathyal depths. These species are Eponides leviculus, C. cushmani, and Epistominella bradyana.

A subgrouping of this biofacies is composed of an assemblage that is indicative of lower middle bathyal environments. Characteristic species are Bulimina subacuminata, Uvigerina hispida, Uvigerina proboscidea vadescens, and Cassidulina laevigata carinata. The total age range of this assemblage is from the early Pliocene to Pleistocene, although the assemblage occurred maximally within the late Pliocene to Pleistocene. This assemblage most closely resembles the Venturian stage.

The second grouping (Lower Bathyal Biofacies), the most abundant faunal assemblage, consists of lower bathyal species. The major constituents are Bulimina rostrata, Uvigerina senticosa, Uvigerina proboscidea, and Bolivinita cf. B. minuta. Deposition of this assemblage took place from the late Miocene to the Pleistocene; the assemblage is composed of species associated with the Repettian stage.

A few species that are in the third grouping (Upper Bathyal Biofacies) are indicative of the middle bathyal environments: species such as Sphaerodina bulloides, Eggerella bradyi, and Uvigerina kernensis subcalva. The majority of species within this group are representative of shallower upper bathyal conditions: Ehrenbergina compressa, Angulogerina angulosa, Epistominella pacifica, and Eponides subtenera. It should be noted that this assemblage was deposited from the late Miocene to the Pliocene. The most abundant occurrence of this grouping is within the Pliocene.

The fourth grouping (Upper Middle Bathyal Biofacies) is composed of species related to upper middle bathyal environments; these species were deposited predominantly during the late Miocene to early Pliocene; they include Globobulimina pacifica, Eponides healdi, Cassidulina margareta, Uvigerina senticosa adiposa, Eponides rosaformis, and Epistominella pontoni californica. Also occurring with this group, but in only a few of the samples, were other species (Siphogenerina basispinata, Cassidulina crassa, and Bolivinia sinuata) indicative of the Mohnian-Delmontian stages of the late Miocene. Because of their low abundance, these species were deleted from the cluster analysis. This grouping probably represents the middle bathyal equivalent of the early Delmontian to late Mohnian stages.

The fifth grouping (Middle Bathyal Biofacies) is characteristic of upper to lower middle bathyal depth habitats. Characteristic species are Cibicides mckanni, Laticarinina pauperata, Valvulineria araucana, Bolivina spissa, Plectofrondicularia advena, and Uvigerina peregrina. This assemblage was dominantly deposited in the late Pliocene through the Pleistocene and closely resembles assemblages associated with the Venturian stage. 


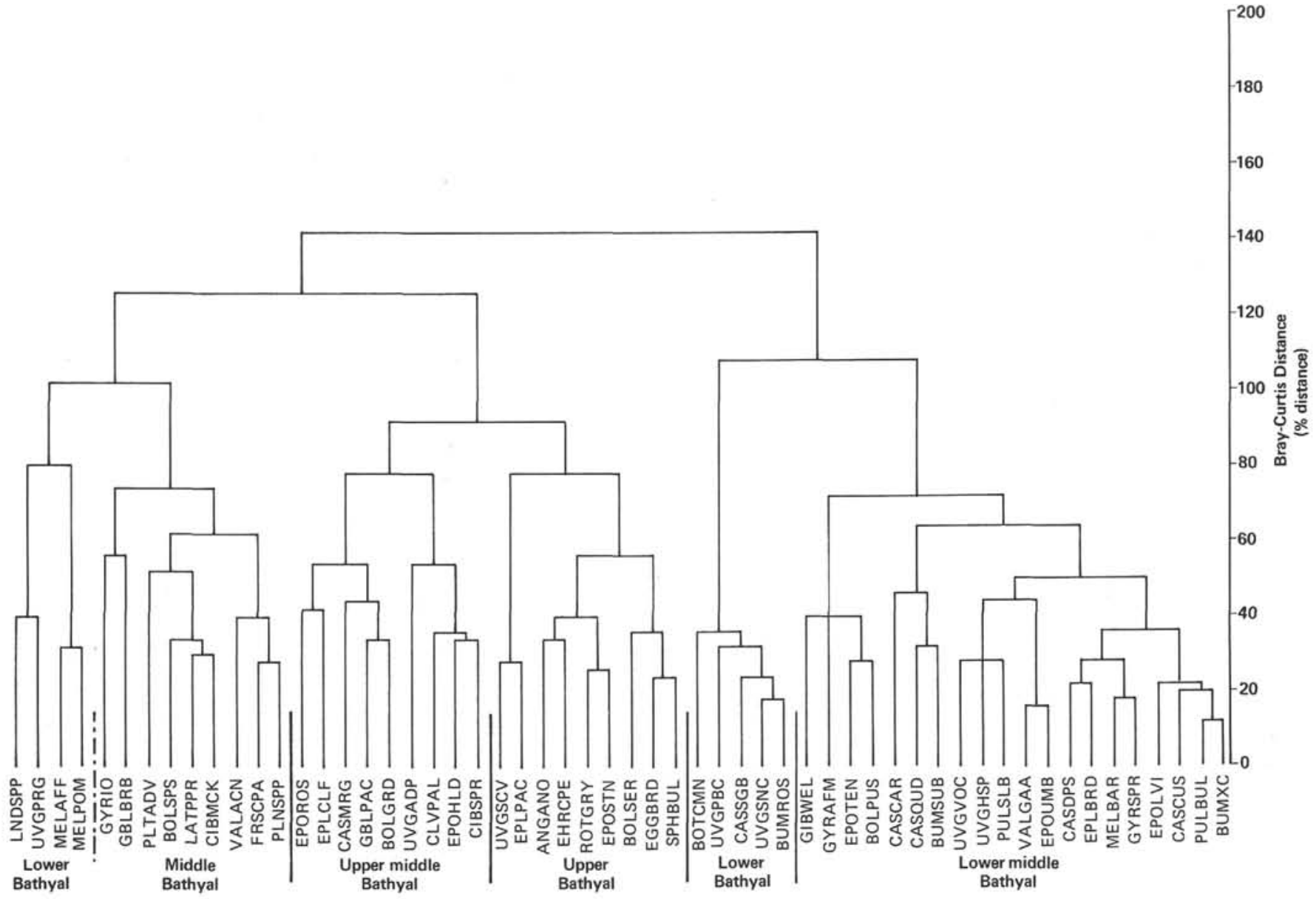

Figure 3. R-Mode (inverse) analysis of Hole 468A. (Major biofacies have been delineated by lines and named on the basis of the characteristic habitat. Species codes used are listed in the Appendix.)

This grouping also contains lower bathyal species $\mathrm{Mel}$ onis pompilioides and Melonis affinis, both indicative of the late Repettian stage. The association of these two species with this grouping is dependent upon their low abundance and number of occurrences and is not necessarily related to their depth habitat.

\section{Hole 468B}

\section{Lithologic Units}

Unit 1 was not recovered in Hole 468B, which was washed to a sub-bottom depth of 16.5 meters. As in Hole 468A, Unit 2 consists of interbedded, light-colored foraminiferal nannofossil ooze and dark-colored nannofossil foraminiferal ooze. The boundary between Units 2 and 3 is shown in Figure 4; it occurs within Section 468B3-1 (at a sub-bottom depth of $35.5 \mathrm{~m}$ ). Unit 3 is composed of interbedded, pale olive nannofossil ooze and olive brown, diatomaceous nannofossil ooze. Sponge spicules, which read concentrations of $10 \%$ or more, are an important component of the sediments. Terrigenous components (clay, silt, and minor sand) increase downsection in Unit 3. The top of Sub-unit 4a is Section 468B-13-1, at 149 meters depth (Fig. 4). This unit continues down to the total depth of $\mathbf{4 1 5 . 5}$ meters. Dolomitic silty claystone and interbedded volcaniclastic rocks are the dominant sediments in this unit.

\section{Preservation}

As previously noted, in this hole benthic foraminifers are very abundant to common within the middle Miocene to Pleistocene sediments from Cores 1 to 15 . There are a few species present within Cores 16 to 18 . Cores 19 through 37 are completely barren of foraminifers. As shown in Table 2, the $\mathrm{P} / \mathrm{B}$ ratios demonstrate a major dissolution fauna below Core 1 ( $27 \mathrm{~m}$ sub-bottom depth), with an almost complete dissolution of planktonic foraminifers.

\section{Benthic Foraminiferal Stages}

Hole 468B was the deepest hole drilled at Site 468, although only the upper 200 meters contain benthic foraminiferal faunas; these sediments range in age from middle Miocene to late Pliocene. As in Hole 468A, the majority of the section is dominated by a lower bathyal assemblage that is characteristic of the Repettian stage. Unlike Hole 468A, there is a well-developed Luisian assemblage present in the lower portion of this hole; however, in all other sections of this hole, it is still difficult to apply stage designations. (It should be noted 


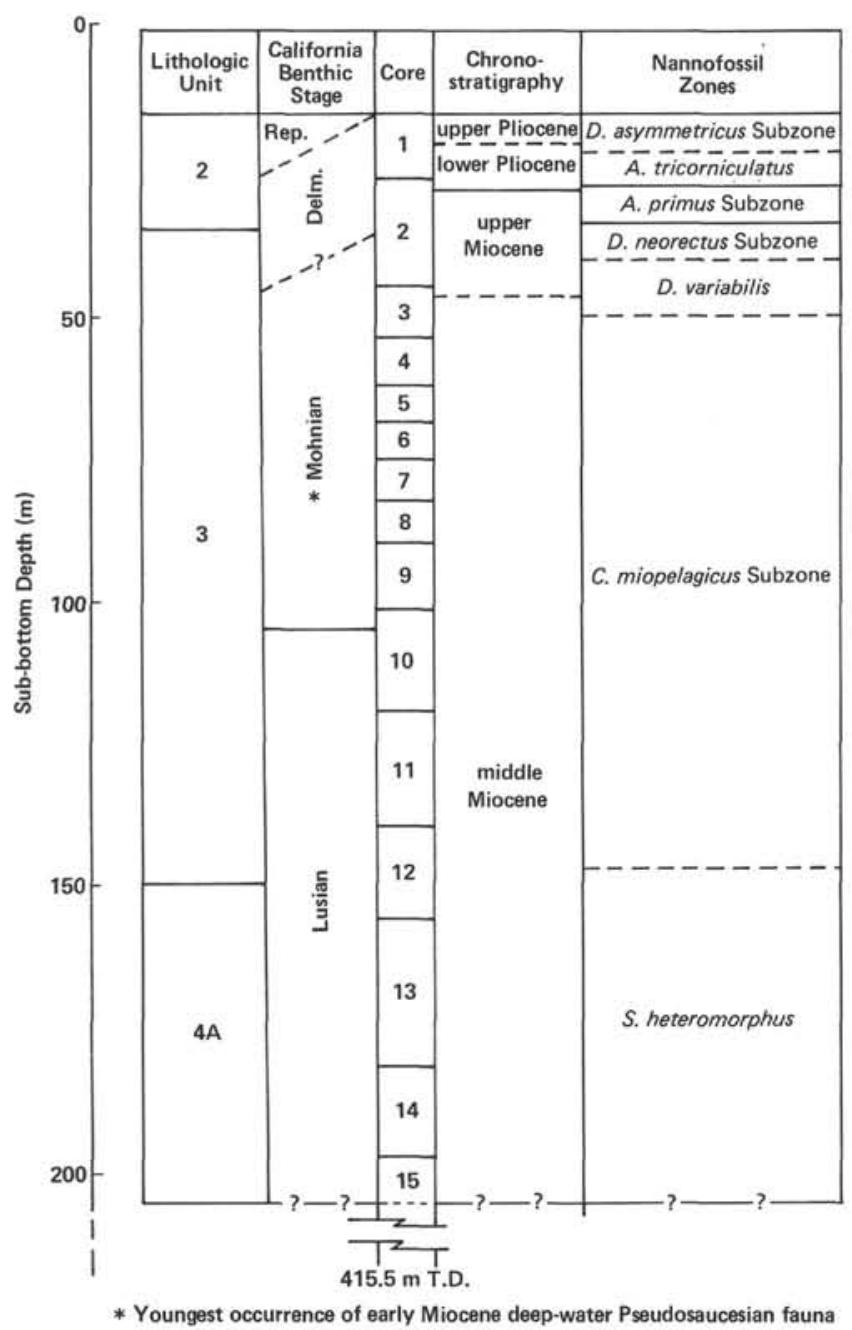

Figure 4. Biostratigraphic correlation of benthic foraminiferal stages to nannofossil zones in Hole $468 \mathrm{~B}$. (In the Mohnian stage, the youngest occurrence was early Miocene deep-water Pseudosaucesian fauna.)

again that the stage designations made are on the basis of a relatively small percentage of the total fossil population.)

As shown in Figure 4, Hole 468B can be divided into four benthic stages. The Repettian is based on Melonis pompilioides, Bulimina rostrata, Pullenia bulloides, Cibicides spiralis, and Uvigerina proboscidea. These species are indicative of lower bathyal water depths.

The Delmontian stage is poorly represented as a faunal stage. In this preliminary study, the stage has been tentatively designated on the basis of the rare occurrences of Valvulineria araucana malagaensis, Fursenkoina complanata, Eponides keenani, Fursenkoina bramletti, and Uvigerina cf. $U$. modeloensis. These species are related to more oxygen-deficient environments of the upper and middle bathyal depths and are only associated with the species that usually designate the Delmontian stage.

The Mohnian is also poorly represented in this hole. Species that are considered to be characteristic of the stage (Bulimina uvigerinaformis, Bolivina bramletti, and Bolivina floridana) occur rarely in only a few samples. In contrast, other species that are usually associated with Mohnian assemblages, such as Cassidulina crassa, Baggina californica, Epistominella pontoni, and Globobulimina pacifica, occur in this hole throughout the middle and upper Miocene. The restricted nature of some assemblages and extended ranges of others is probably dependent on environmental restrictions and not totally related to the stratigraphic range of the included species.

In Hole 468B the Luisian stage is the best developed benthic stage in the middle Miocene. Its first occurrence is in Core 10, and it ranges to at least Core 15. Characteristic species of this stage include Bolivina advena striatella, Bolivina advena ornata, Anomalina salinasensis, Baggina californica, and Bolivina californica. The middle bathyal assemblage indicative of this stage is represented by several species, unlike the other benthic stages of the late Miocene. In addition, index species such as Siphogenerina nuciformis, Baggina robusta, and Valvulineria miocenica occur, but in smaller percentages.

In Hole 468B there is the occurrence of a middle Miocene lower bathyal fauna that contains species characteristic of the early Zemorrian and Saucesian. This deep-water assemblage has been called the "Pseudosaucesian" by Rudel (1968) and Bandy and Arnal (1969). Characteristic species of this assemblage include Sphaeroidina variabilis, Melonis pompilioides, Plectofrondicularia californica, Gyroidina soldanii altiformis, and Uvigerina mexicana. There are several other species that could also be placed within the Pseudosaucesian. They are Bulimina corrugata, Pullenia bulloides, Uvigerina senticosa, and Uvigerina hispida (of Kleinpell, 1938). These additional species probably represent a deeper-water facies of the Pseudosaucesian than has been recorded within the San Joaquin Valley. As will be discussed in more detail later, this assemblage has a strong similarity to the lower bathyal faunas of the Repettian stage.

The faunal data from Hole 468B were also subjected to cluster analysis, and the classification resulted in five recurrent groups (Fig. 5). The first grouping (Middle Bathyal Biofacies) consists of $L$. pauperata, B. subacuminata, E. leviculus, and $A$. angulosa. This middle bathyal assemblage was deposited in the late Miocene to Pliocene and represents the Venturian stage.

The second grouping (Upper Bathyal Biofacies) has close faunal affinities to the Middle Bathyal Biofacies, as demonstrated by the R-mode dendrogram (Fig. 5). This assemblage is composed of species indicative of upper bathyal to upper middle bathyal depth habitats. The major constitutents of this grouping are C. mckannai, E. pacifica, C. cushmani, E. bradyana, and E. subtenera. The occurrence of this assemblage ranges from the middle Miocene to Pliocene, however, it occurred maximally within the late Miocene through Pliocene.

The third grouping (Lower Bathyal Biofacies) is almost identical to the Lower Bathyal Group in Hole 468A (Fig. 3). It consists of species that are indicative of lower middle to lower bathyal depths and occurs 


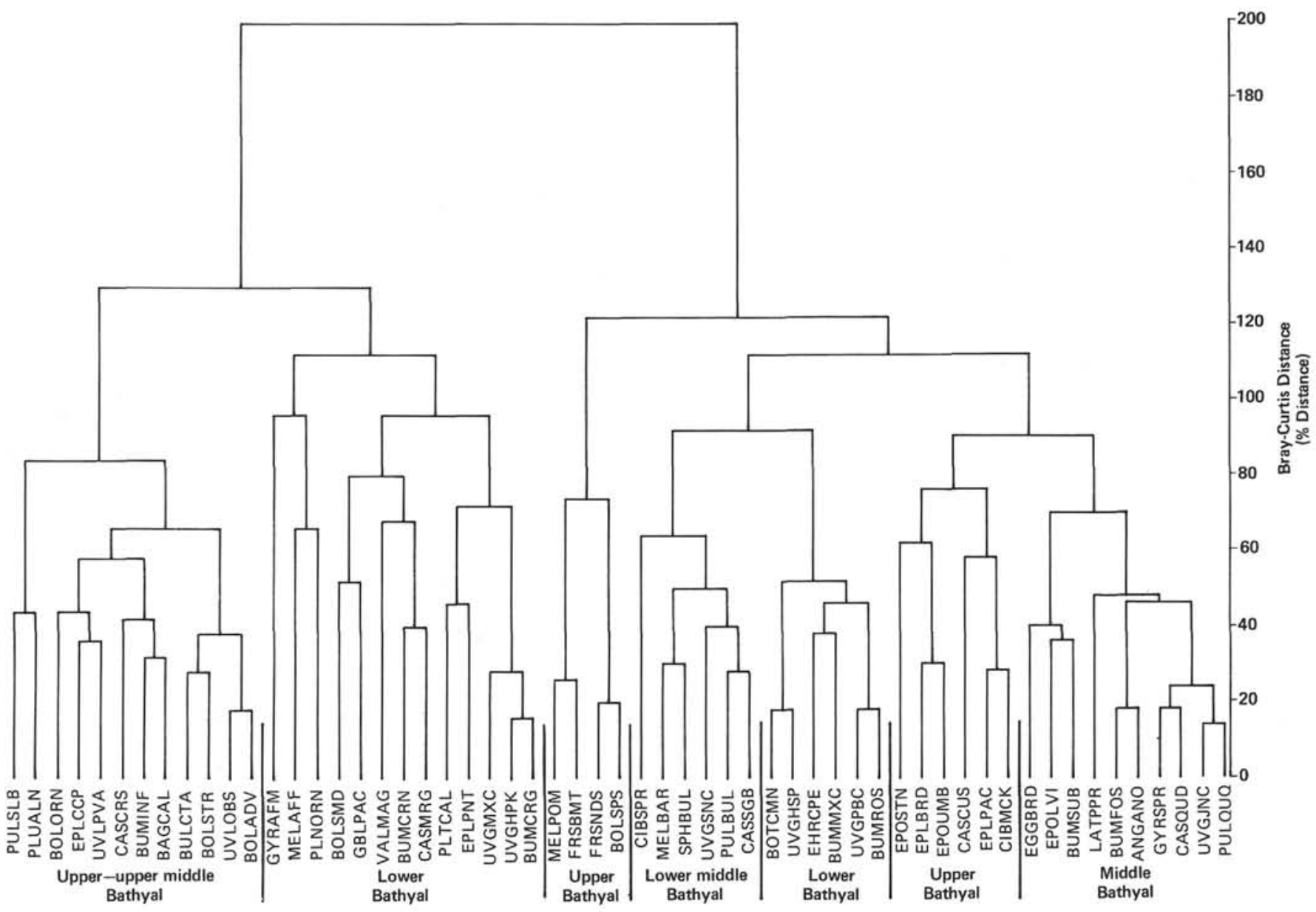

Figure 5. R-Mode (inverse) analysis of Hole 468B. (Major biofacies have been delineated by lines and named on the basis of the characteristic habitat. Species codes used are listed in the Appendix.)

throughout the section from middle Miocene to Pliocene, although it was most dominantly deposited within the late Miocene to Pliocene. Characteristic species are Uvigerina hispida, Bulimina rostrata, B. mexicana, $U$. proboscidea, and B. cf. B. minuta. These are characteristic species of the Repettian stage but are also minor components of the Pseudosaucesian.

The fourth grouping (Lower Middle Bathyal Biofacies), which has a close faunal affinity to the Lower Bathyal Biofacies, is the most cosmopolitan of the faunal groupings. It is composed of species that are indicative of lower middle bathyal environments. The major constituents of this grouping are $P$. bulloides, $U$. senticosa, S. bulloides/variablis, M. barleeanum, and C. spiralis. This assemblage occurs throughout Hole $468 \mathrm{~B}$ and represents characteristic species of the Repettian and is a major component of the middle Miocene Pseudosaucesian.

The fifth grouping (Upper Bathyal Biofacies) is not characteristic of any particular stage or depth habitat. The characteristic species are Fursenkoina nodosa, $F$. bramletti, Bolivina spissa, and $M$. pompilioides. The occurrence of this group is restricted to the oldest Pliocene and the youngest Miocene and probably represents a mixture of specific Repettian species and Delmontian species that occur together. It should be noted that this assemblage does closely resemble the Middle Bathyal grouping of Hole 468A (Fig. 3).

The sixth grouping (Lower Bathyal Biofacies) consists of two subgroups, both indicative of two different depth habitats. The first subgroup consists of $U$. hispida (of Kleinpell), $U$. mexicana, Bulimina corrugata, $P$. californica, and $G$. soldanii altiformis-species characteristic of the lower bathyal Pseudosaucesian. This assemblage is restricted to the middle Miocene and occurs from Core 8 to Core 15 (Fig. 4). The other subgroup is composed of upper to upper middle bathyal species such as C. margareta, G. pacifica, B. seminuda, and E. pontoni. This assemblage is probably equivalent to the late Mohnian-early Delmontian and closely resembles the Upper Middle Bathyal group of Hole 468A. Deposition of both of these groupings took place within the late Miocene.

The last grouping (Upper to Upper Middle Bathyal Biofacies) consists of faunas that occur predominantly in the middle Miocene. This assemblage contains Bolivina advena striatella, Buliminella curta, Bulimina inflata, Bolivina advena ornata, Uvigerinella californica 
parva, and Baggina californica. These species are indicative of upper to middle bathyal environments and are important representatives of the Luisian stage.

\section{PALEOENVIRONMENTAL INTERPRETATION OF SITE $\mathbf{4 6 8}$}

The dominant faunal assemblage that occurs at Site 468 is a lower bathyal biofacies that ranges from the middle Miocene to the Pleistocene. Although the stratigraphic sections can be broken into stage designations, the Pseudosaucesian-Repettian fauna probably represents the lower bathyal conditions that existed during deposition of the total sedimentary record at Holes $468 \mathrm{~A}$ and $468 \mathrm{~B}$.

To show the stratigraphic relationship more graphically between the different biofacies as defined by cluster analysis, the relative abundance of each biofacies has been plotted against age and depth in the well (Fig. 6). As has been stated, these sediments were deposited in a lower bathyal environment since the middle Miocene. In the middle Miocene, this assemblage was represented by the Pseudosaucesian, and in the late Miocene to Pleistocene, by the Repettian. It should be noted that there are

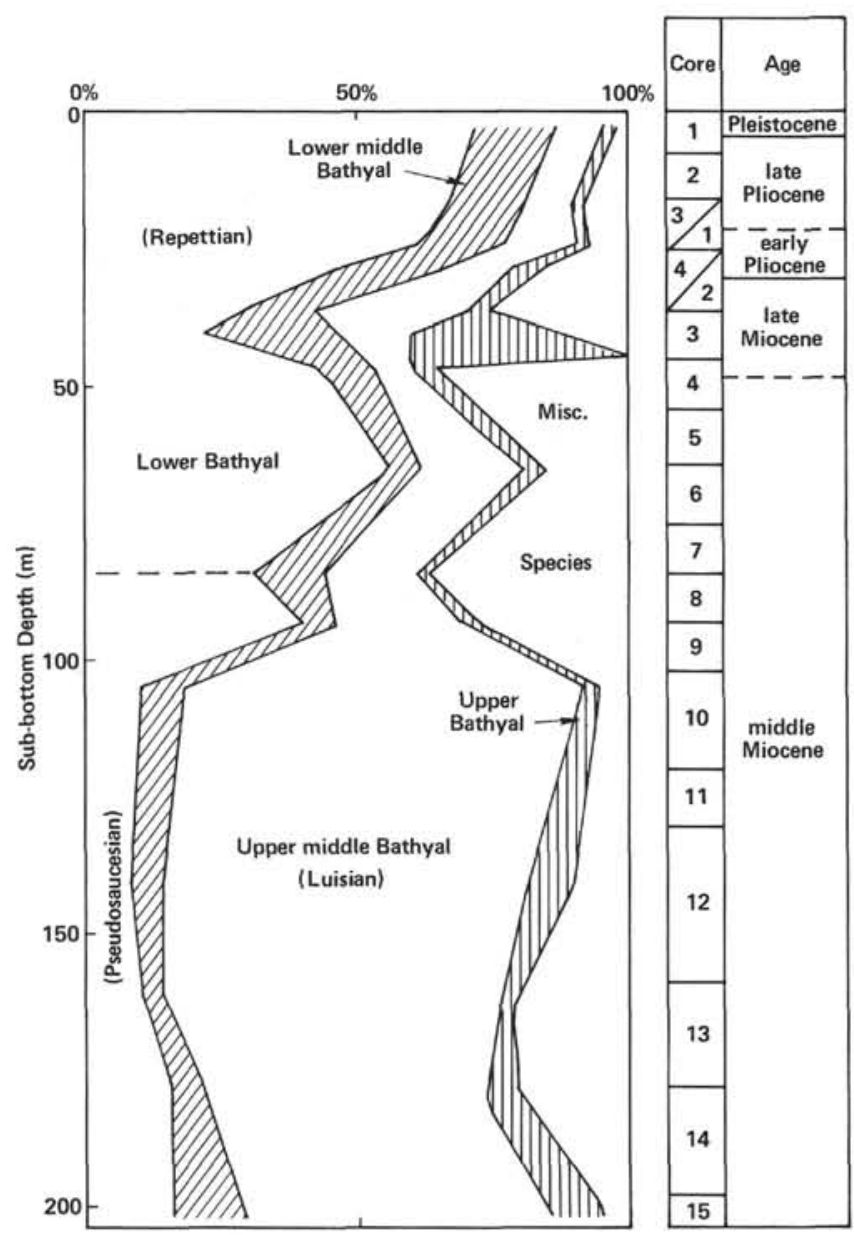

Figure 6. Variation of benthic foraminiferal biofacies at Site 468. (See Figs. 3 and 5 for the species composition of benthic biofacies.) species occurring in both of these faunal assemblages that range from middle Miocene to Pleistocene.

In the late Miocene to Pleistocene interval, there is a well-defined lower middle bathyal assemblage that is representative of the Venturian faunas. It also contains relatively shallower-water faunas (upper bathyal to middle bathyal) that are represented by species characteristic of the Mohnian and Delmontian stages.

In the upper portion of the middle Miocene, at Section 468B-9-1 (90 meters sub-bottom depth), there is a major decrease in the dominance of the lower bathyal assemblages and an increase in the abundance of the middle bathyal species that are characteristic of the Luisian (Fig. 6). This major faunal change could be the response to an oceanographic variation or to a possibly decreased displacement of middle bathyal species into the deeper-water environment in the late Neogene.

It has been shown that the distribution of lower bathyal benthic assemblages in the eastern Pacific Ocean is related to the oceanographic distribution of Antarctic bottom-water mass (Blake and Douglas, 1980). Any variation in the water-mass boundary conditions will result in a variation in distribution patterns of the deeper-water benthic faunas, especially if the fluctuation is associated with glacial-interglacial changes (Streeter, 1973).

The major increase in dominance of the Pseudosaucesian-Repettian is in the Coccolithus miopelagicus Subzone of the middle Miocene (approximately 13 to 14 Ma). Berggren and Hollister (1977) have noted that in the Pacific Ocean basin at approximately this time interval there was a marked increase in the subarctic convergence. This increase could possibly have been related to or caused an increase in bottom-water production. The additional influx of bottom-water would have resulted in a rearrangement of the water masses and possibly the expansion and migration of the lower bathyal depth habitat and the associated assemblages into the middle bathyal environments.

\section{CONCLUSIONS}

The benthic foraminiferal populations that occur in Holes $468 \mathrm{~A}$ and $468 \mathrm{~B}$ are dominated by deep-water assemblages. For this reason, the relatively shallowerwater late Miocene benthic stages are difficult to identify, because species used for stage designations represent only small percentages of the total populations.

The Neogene benthic foraminiferal assemblages are characteristic of four depth habitats. In addition, it appears that the benthic assemblages that define the benthic stages are also related to distinct biofacies. The Repettian and Pseudosaucesian assemblages are characteristic of a lower bathyal biofacies. Lower middle bathyal biofacies are represented by the Luisian and Delmontian stages. The upper bathyal biofacies is usually a minor component and consists of species associated with the Mohnian and Delmontian stages.

The Pseudosaucesian assemblage was common and well-preserved in Hole 468B. It consists of lower bathyal 
species representative of the Zemorrian and Saucesian as well as Repettian faunas. It is a major component of the Mohnian and Luisian stages.

As shown in this preliminary study, many of the index species for the Miocene benthic stages are not numerically significant in these holes, because they are characteristic of relatively shallower habitats. Their presence in the deeper-water environments is related to the amount of displacement and not necessarily to their total occurrence range in shallower environments.

Before the significance of the relationship between habitat and distribution of benthic stages can be established, the remaining sites of Leg 63 will have to be scrutinized. I hope to complete a detailed listing of these sites in the future, in addition to providing more information on the Pseudosaucesian and its role in benthic foraminiferal biostratigraphy. Because different stages are indicative of different habitats, there is the possibility of the benthic stages occurring together. The overlap between stages could be related to the displacement of the relatively shallower faunas into the deeper-water environments and/or to changes in water-mass structure. The environmental history will have to be established before we can determine the temporal variations of the benthic stages between the outer Continental Borderland and land sections.

\section{REFERENCES}

Bandy, O. L., 1953. Ecology and paleoecology of some California foraminifera. Part I: The frequency distribution of Recent foraminifera off California. J. Paleont., 27:161-182.

1971. Neogene planktonic foraminiferal zones, California, and some geologic implications. Palaeogeogr. Palaeoclimatol. Palaeoecol., 12:131-150.

Bandy, O. L., and Arnal, R. E., 1969. Middle Tertiary basin development, San Joaquin Valley, California. Bull. Geol. Soc. Am., $80: 783-820$.

Bandy, O. L., and Chierici, M. A., 1966. Depth-temperature evaluation of selected California and Mediterranean bathyal foraminifera. Mar. Geol, 4:259-271.

Berggren, W. A., and Hollister, C. D., 1977. Plate tectonics and paleocirculation. Commotion in the ocean. Tectonophysics, 38: $11-48$.

Blake, G. H., 1976. The distribution of benthic Foraminifera in the outer Borderland and its relationship to Pleistocene marl biofacies. [M. S. thesis]. University of Southern California.

Blake, G. H., and Douglas, R. G., 1980. Pleistocene occurrence of Melonis pompilioides in the California Borderland its implication for foraminiferal paleoecology. Cushman Found. Foraminiferal Res. Publ., 18:59-67.

Crouch, J. K., and Bukry, D., 1979. Comparison of Miocene provincial foraminiferal stages to coccolith zones in the California Continental Borderland. Geology, 7:211-215.

Ingle, J. C., Jr., 1967. Foraminiferal biofacies and the Miocene-Pliocene boundary in southern California. Am. Paleontol. Bull., 52: 210-394.

1973. Neogene Foraminifera from the Northeastern Pacific Ocean, Leg. 18, DSDP. In Kulm, L. D., von Huene, R. et al., Init. Repts. DSDP, 18: Washington (U.S. Govt. Printing Office), 517-567.

Kleinpell, R. M., 1938. Miocene stratigraphy of California: Tulsa, Oklahoma (Am. Assoc. Petroleum Geologists), pp. 1-450.

Natland, M. L., 1952. Pleistocene and Pliocene stratigraphy of southern California [Ph.D. thesis]. University of California, Los Angeles.

Rudel, C. H., 1968. Biofacies of the lower Mohnian. In Karp, S. E. (Ed.), Guidebook to West Side Southern San Joaquin Valley: Bakersfield (Pacific Section. A.A.P.G.), pp. 92-93.
Smith, R. W., 1976. Numerical analysis of ecological survey data [Ph.D. thesis]. University of Southern California.

Streeter, S., 1973. Bottom water and benthonic foraminifera in the North Atlantic glacial-interglacial contrasts. Quat. Res., 3: 131-141.

APPENDIX

Species Codes Used in Figures $\mathbf{3}$ and $\mathbf{5}$

$\begin{array}{ll}\text { ANGANO } & \begin{array}{l}\text { Angulogerina angul } \\ \text { BAGCAL }\end{array} \\ \text { BOLgina californica }\end{array}$

BOLGRD B. girardensis

BOLORN $\quad B$. advena ornata

BOLPUS B. pusilla

BOLSER $\quad B$. aenariensis serrata

BOLSMD B. seminuda

BOLSPS B. spissa

BOLSTR $\quad B$. advena striatella

BOTCMN Bolivinita cf. B. minuta

BULCTA Buliminella curta

BUMCRG Bulimina corrugata

BUMCRN B. carnerosensis

BUMFOS B. fossa

BUMINF $\quad B$. inflata

BUMMXC B. mexicana

BUMROS B. rostrata

BUMSUB B. subacuminata

CASCAR Cassidulina laevigata carinato

CASCRS C. crassa

CASCUS C. cushmani

CASDPS C. depressa

CASMRG C. margareta

CASQUD C. subglobosa quadrata

CASSGB C. subglobosa

CIBMCK $\quad$ Cibicides mckannai

CIBSPR C. spiralis

CIBWEL C. wellerstorfi

CLVPAL Clavulina pallida

EGGBRD Eggerella bradyi

EHRCPE Ehrenbergina compressa

EPLBRD Epistominella bradyana

EPLCCP E. cf. E. capitanensis

EPLCLF E. pontoni californica

EPLPAC $\quad E$. pacifica

EPOHLD Eponides healdi

EPOLVI E. leviculus

$\begin{array}{ll}\text { EPOLVI } & \text { E. leviculus } \\ \text { EPOROS } & E \text {. rosaformis }\end{array}$

EPOSTN E. subtenera

EPOTEN $E$, tenero

EPOUMB E. umbonatus

FRSBMT Fursenkoina bramlette

FRSCPA $F$. complanata

FRSNDS F. nodosa

GBLBRB Globobulimina barbata

GBLPAC G. pacifica

GYRAFM Gyroidina soldanii altiformis

GYR10

GYRSPR G. spiralis

LATPPR Laticarinina pauperate

LNDSPP Lenticulina species

MELAFF Melonis affinis

MELBAR M. barleeanum

MELPOM M. pompilioides

PLNORN Planulina ornata

PLNSPP Planulina species

PLTADV Plectofrondicularia advena

PLTCAL P. californica

PLUALT Pleurostomella alternans

PULBUL Pullenina bulloides

PULQUQ $\quad P$. quinqueloba

PULSLB $\quad P$. salisburyi

ROTGRY Rotalia

SPHBUL Sphaerodina bulloides/variablis

UVGADP Uvigerina senticosa adipasa

UVGHPK U. hispida (of Kleinpell)

UVGHSP U. hispida

UVGJNC $U$. juncea

UVGMXC U. mexicana

UVGPBC U. proboscidea

UVGPRG $U$. peregrina

UVGSCV U. kernensis subcalva

UVGSNC U. senticosa

UVGVDC $\quad U$. proboscidea vadescens

UVLOBS Uvigerinella obesa

UVLPVA U. californica parva

VALACN Valvulineria araucana

VALGAA V. glabra

VALMAG $V$. araucana malagaensis 